\title{
Semi-natural and intensive silvicultural systems for the boreal mixedwood forest
}

\author{
by V. J. Lieffers ${ }^{1}$, R. B. Macmillan ${ }^{2}$, D. MacPherson ${ }^{3}$, K. Branter $^{4}$ and J. D. Stewart ${ }^{1}$
}

Boreal mixedwood forests of aspen (Populus tremuloides) and white spruce (Picea glauca) are found on mesic sites in the western boreal forest. In the natural development of mixedwood stands, aspen is usually the first species to dominate the site. However, depending upon spruce seed sources and seedbeds, spruce can establish immediately after disturbance or in the next several decades. In most cases, spruce grow in the understory of deciduous species during its early development. If there are no spruce seed sources, aspen may be the sole tree species for a long period. In most circumstances, however, the longer-lived and taller white spruce eventually becomes the dominant species. If stands remain undisturbed for long periods, they will likely become uneven-aged mixtures of spruce and balsam fir (Abies balsamea). We propose silvicultural systems that will develop stands of a range of compositions, structures and value. As a starting point, we identify eight different mixedwood compositions that might be identified in stand inventories, and propose various silvicultural treatments, including underplanting of white spruce, understory protection, shelterwood, and unevenaged management. Fundamental changes in land tenure and silvicultural regulations, and improvements in estimation of growth and yield will be required before this range of management of mixedwoods can be implemented.

Key words: aspen, white spruce, shelterwood, Populus tremuloides, Picea glauca, succession, ecosystem management
Les forêts mélangées nordiques composées de peuplier fauxtremble (Populus tremuloides) et d'épinette blanche (Picea glauca) se retrouvent sur les sites mésiques des forêts boréales de l'ouest. Au cours de l'évolution naturelle des peuplements mélangés, le peuplier faux-tremble est habituellement la première espèce à dominer le site. Toutefois, en fonction de la source de semences d'épinette et du lit de germination, l'épinette peut s'établir immédiatement après une perturbation ou au cours des quelques décennies qui suivent. Dans la plupart des cas, l'épinette croit en sous-étage des espèces feuillues au cours de son développement initial. S'il n'y a pas de source de semences d'épinette, le peuplier faux-tremble peut constitué la seule espèce présente peur plusieurs années. Dans la plupart des circonstances, cependant, l'épinette blanche quia une durée de vie plus longue et qui est plus imposante, devient éventuellement l'espèce dominante. Si les peuplements ne sont pas perturbés au cours d'une longue période, ils se transformeront vraisemblablement en un mélange inéquienne d'épinette et de sapin baumier (Abies balsamea). Nous suggérons des régimes sylvicoles qui permettront le développement de peuplements en fonction d'une sélection au niveau de la composition, des structures et des valeurs. En tant que point de départ, nous identifions huit regroupements différents d'espèces mélangées qui peuvent être reconnus lors de l'inventaire des peuplements, et nous proposons différents traitements sylvicoles, dont la plantation en sous-étage de l'épinette blanche, la production en sous-étage, la coupe progressive, et l'aménagement inéquienne. Des modifications fondamentales au niveau de la tenure du territoire et des règlements sylvicoles, ainsi que l'amélioration des estimations de la croissance et du rendement seront requises avant d'être en mesure d'implanter ces possibilités d'aménagement des peuplements mélangés.

Mots clés: peuplier faux-tremble, épinette blanche, coupe progressive, Populus tremuloides, Picea glauca, succession, aménagement écosystémique

\section{Introduction}

In the last decade there has been an increase in the awareness of forests as natural ecosystems and the importance of public land forests for wildlife, recreation and biodiversity benefits. This has resulted in the development of the concepts of ecosystem management. Rowe (1992) cites the Ontario Wildlife Working Group's definition of ecosystem management as "adopting an holistic view of the natural world, recognizing the complexities and interconnections of ecosystems, taking account of the dynamic nature and finite capacities of the ecosystems and encouraging collaboration among those whose activities affect ecosystems". An overall ecosystem management strategy for forested lands would include some intensively managed

\footnotetext{
${ }^{1}$ Department of Renewable Resources, University of Alberta, Edmonton, Alberta, Canada T6G 2H1.

${ }^{2}$ Weyerhaeuser Canada, Ltd., Alberta Div. 11553 - 154 St., Edmonton, Alberta, Canada T5M 3N7.

${ }^{3}$ Alberta Pacific Forest Industries Inc., P.O. Box 8000, Boyle Alberta, Canada TOA OMO.

${ }^{4}$ Alberta Lands and Forest Services, Forest Management Division, Edmonton, Alberta, Canada. Currently at: Sunpine Forest Industries, Box 1 Sundre, Alberta TOM $1 \mathrm{X} 0$.
}

areas, but managers would also have to maintain a large percentage of the landbase in a semi-natural pattern (Rowe 1992; Lieffers and Beck 1994). These patterns must be based, in part, on natural disturbance regimes (Hunter 1991) and other natural processes.

In Alberta the mixedwood land areas are currently designated as coniferous (C) or deciduous (D) landbase depending upon the volume of conifer in the stand at the time of inventory. Currently, management has been biased towards white spruce [Picea glauca (Moench) Voss] and most of the silvicultural activities associated with these mixedwood systems have been aimed at establishing relatively pure stands of white spruce (Lieffers and Beck 1994). Regeneration of white spruce in plantation following clearcutting, however, has been difficult (Navratil et al. 1991) and expensive (Benson 1988). White spruce has slow juvenile growth rates (Nienstadt and Zasada 1990) and, in early successional vegetation types, is usually overtopped by fast growing hardwoods and grass (Drew 1988; Lieffers et al. 1993). On lands designated as deciduous, there is little attempt to grow conifers even though in many circumstances the sites could grow coniferous as well as deciduous species. Pure deciduous stands do not attain the yield benefits of growing shade tolerant conifers in the understory of intolerant hardwoods 
(Anonymous 1985; Kelty 1989; Burkhart and Tham 1992) nor will pure stands achieve the biodiversity values of mixed stands (Burton et al. 1992).

In recent years, silviculture has become synonymous with establishment of forest plantations (Lavender et al. 1990). Silviculture should, however, be defined broadly as the theory and practice of controlling forest establishment, composition and growth (Smith 1986). Knowledge of ecological processes is critical for predicting the development of ecosystems following management activities. If we wish to produce forests that resemble the wide range of compositions and structures that are found naturally, but at the same time allow significant utilization of the wood resource, we will have to apply innovative silvicultural treatments that develop forest ecosystems of a target composition and structure (Oliver 1992).

In this paper the natural development patterns of boreal mixedwood stands in western Canada is examined, and a range of silvicultural options to produce stands of a wide range of structures is suggested.

\section{Natural Stand Development in Boreal Mixedwood Forests}

In the western boreal forest, mixedwood forests are found on mesic or zonal forest sites. They are dominated by mixtures of trembling aspen (Populus tremuloides Michx.) and white spruce (Rowe 1972) with some intermixing of balsam poplar (Populus balsamifera L.), paper birch (Betula papyrifera Marsh.), black spruce [Picea mariana (Mill.) B.S.P.], balsam fir [Abies balsamea (L.) Mill.] and pines (Pinus spp.). Most natural mixedwood stands originated after fire (Rowe and Scotter 1973), and can range from pure stands of white spruce to pure aspen, and mixtures of the two in varying proportions (Corns and Annas 1986). Complexity in stand development for boreal mixedwoods arises because of differences in recruitment strategies, shade tolerances, juvenile growth rates, and lifespan/time to maturity of the main species. The structure and composition of mixedwoods also are influenced strongly by time since disturbance, amount of forest floor removal, survival of root stocks, and seed sources. These factors can be categorized as stand history (McCune and Allen 1985). The various successional pathways of boreal mixedwood forests are proposed in Fig. 1.

Early mixedwood stand development depends largely upon the intensity of disturbance to the forest floor, and the availability of seed sources or vegetative reproductive organs. The loss of forest floor organic material (duff) increases with the severity of fire (Rowe and Scotter 1973). Light surface fires will give sprouting species such as aspen (Peterson and Peterson 1992) or Calamagrostis canadensis (Lieffers et al. 1993) a distinct advantage over species establishing from seed. If the aspen root system is healthy and it survives the disturbance, suckering from roots is rapid (Peterson and peterson 1992). Calamagrostis canadensis, particularly on moister sites, may dominate for a long period if it is not overtopped by woody species such as aspen. Thick beds of $C$. canadensis shade and insulate the soil, resulting in a cold, dark micro-environment which inhibits the establishment and growth of white spruce (Lieffers et al. 1993).

Deep burning fires kill shallow roots and rhizomes and prepare a mineral soil seedbed (Heinselman 1981). This usually results in rapid development of herbaceous vegetation such as fireweed or geranium (Heinselman 1981). The exposed soil on these sites is also an excellent seedbed for recruitment of white spruce and, provided there is a good seed source, these disturbances may be the source for relatively pure, evenaged stands of white spruce (Dix and Swan 1971; Cogbill 1985).

The intermediate stages of mixedwood stand development are differentiated largely by the presence or absence of a white spruce seed source. White spruce may gradually recruit into aspen dominated stands (DeLong 1991; Lieffers et al. 1996), provided that there is a nearby seed source. Aspen canopies transmit increasing amounts of light as they age (Peterson and Peterson 1992), but in general there is sufficient light to support reasonable height growth of white spruce once the spruce is above the shrub layer (Lieffers and Stadt 1994). In this regard, the stem initiation phase of stand development (Oliver and Larson 1990) for understory white spruce continues until spruce plays a dominant role in the canopy. Where white spruce seed trees are absent, the aspen will dominate but gradually lose vigour as they age.

In most circumstances, fire will return older mixedwood stands to an early successional stage before there is any further species replacement (Rowe 1961; Achuff and La Roi 1977; Cogbill 1985). However, overmature mixedwood stands do occur in various forms. Old aspen stands tend to be gradually dominated by shrubs and remain a relatively stable community (Rowe 1961) or occasionally there is some rejuvenation of the aspen component in the stands (Dix and Swan 1971; Carleton and Maycock 1978). In spruce stands, the very shade tolerant balsam fir will establish in the understory if there are seed sources available. If undisturbed, the overstory spruce will decline gradually because of litter buildup and reduction in nutrient cycling (Pastor et al. 1987), or more rapidly by spruce budworm attack (Cogbill 1985; Bergeron and Dubuc 1989). These spruce will be replaced by unevenaged, low density mixtures of balsam fir and spruce (Achuff and La Roi 1977), sometimes mixed with birch and shrubs (Cogbill 1985; Bergeron and Dubuc 1989).

\section{Silvicultural Systems Options for Boreal Mixedwoods}

In our proposed silvicultural systems we chose as our starting point the types of relatively mature stands that are typically found in the forest inventory, recognizing that there is a range of possible densities in each of these types and that these types are points on a continuum of variation. From these we attempted to develop a set of silvicultural options that could be feasibly applied to these stand types (Fig. 2). These options encompass a broad spectrum of silvicultural practice, ranging from low input, extensive systems (e.g. 1a, 2a), to relatively intensive systems (e.g. 2c, 7c).

\section{Single-story Stands}

Relatively pure aspen stands can be regenerated successfully by clearcutting. Suckering should be prolific provided that the root systems are healthy and carbohydrate reserves are high (Peterson and Peterson 1992). Where possible, cutting should be avoided in spring and early summer when carbohydrate levels are at their lowest (Shier and Zasada 1973). Older and faster-growing clones may also have lower carbohydrate reserves (Schier and Johnson 1971). Relatively pure aspen stands could be underplanted with white spruce seedlings. Probably understory site preparation would be needed to reduce shrub/herb vegetation, improve planter access and plantability. Further research 


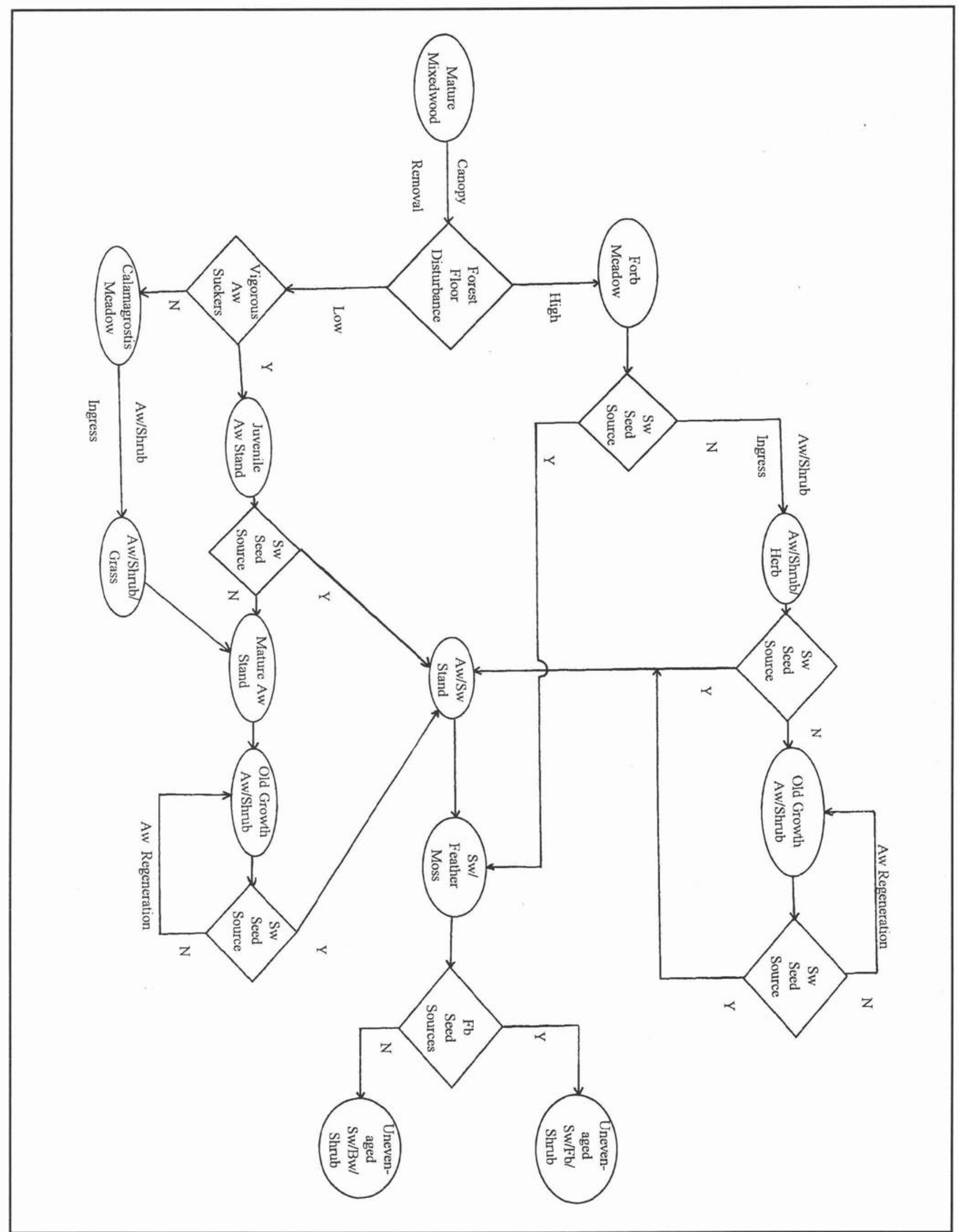

Fig. 1. Successional pathways for boreal mixedwood forests. Derived from the literature cited in the text and personal observations. Aw = aspen, $\mathrm{Bw}=$ paper birch, $\mathrm{Fb}=$ balsam fir, and $\mathrm{Sw}=$ white spruce. 


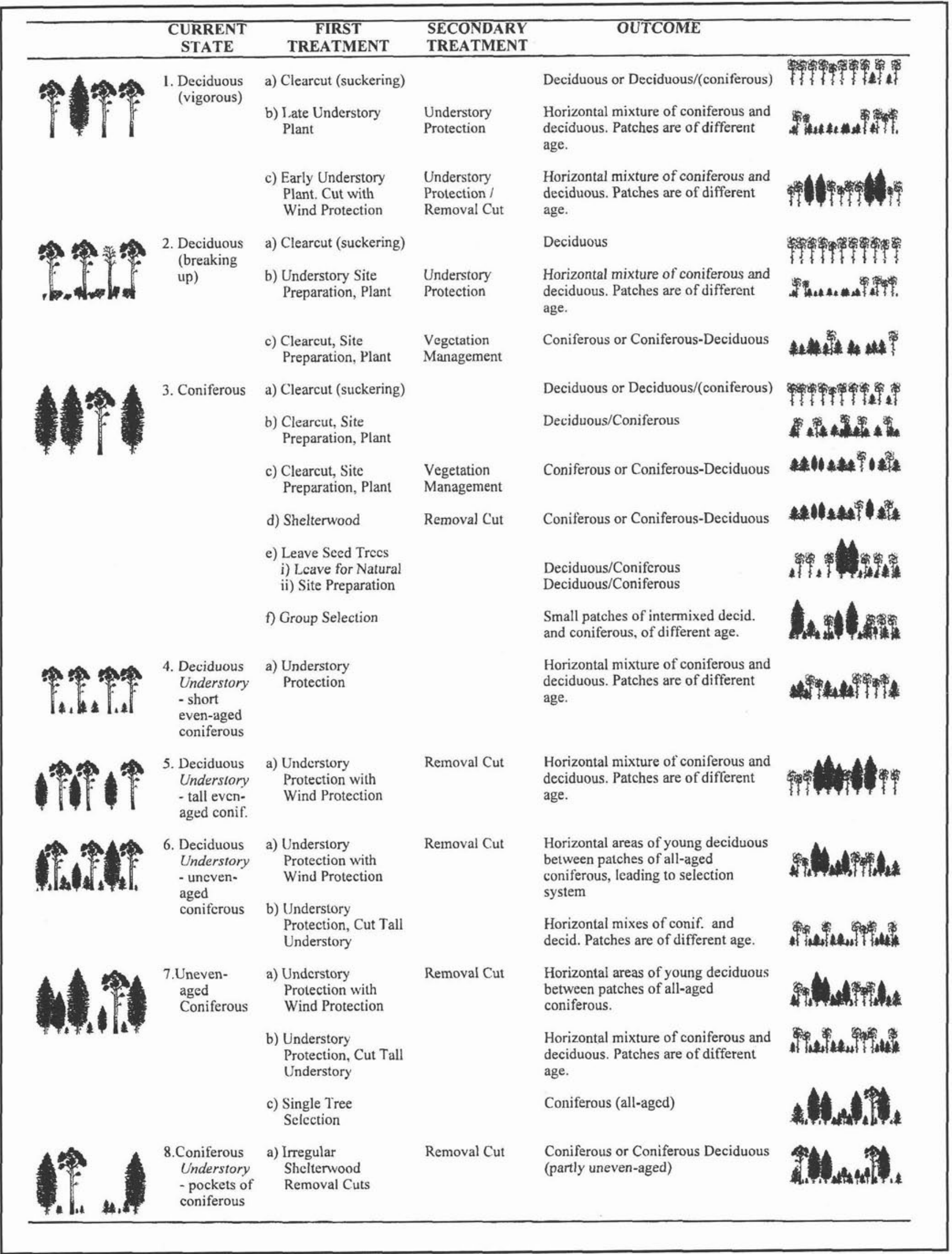

Fig. 2. Silvicultural options for boreal mixedwood forests. 
is required to determine optimal methods of understory site preparation to minimize damage to overstory aspen stems and root systems, and to best promote white spruce establishment and growth. The planting could be done relatively late in the life of the aspen stand, perhaps 10 to 20 years prior to harvesting of the aspen. This would allow sufficient time for the spruce to grow $1 \mathrm{~m}$ in height and therefore be tall enough to be seen and avoided during the harvest of the aspen using understory protection techniques (two stage harvesting regime) (Brace and Bella 1988) and be taller than much of the developing shrub/herb layer. These trees would be above much of the developing shrub and herb vegetation after cutting the aspen, but not be so tall that they would windthrow. In terms of mimicking natural patterns, this system could be compared to patchy fire regimes that leave irregular strips and patches of immature conifer surrounded by burned areas which would sucker back to poplars. It would also be similar to sites where there is patchy establishment of spruce immediately after disturbance. If the white spruce were planted relatively early in the development of the aspen stand, it might afford a total yield advantage as the stand would be in a mixed state for a longer period of time (Kelty 1989). Also, these mixed stands may be more desirable for wildlife/ diversity benefits. In the early planting, white spruce might be at a disadvantage relative to late planting because of lower light transmission by the young overstory aspen (Lieffers and Stadt 1994). When the aspen overstory is removed and the tall understory spruce is protected from logging damage, it is more prone to blowdown unless the overstory is removed in patterns that afford wind protection to the understory spruce (Navratil et al. 1994).

The proposed systems $1 \mathrm{~b}$ and $1 \mathrm{c}$ will require trail systems for machine access into stands. If there is planting of spruce under aspen canopies, the method of harvest of the aspen must be anticipated. Planted spruce should be distributed to allow for trucking and skidding access trails that will not destroy the planted stock. Using current fellerbuncher harvesting systems, this will require $12 \mathrm{~m}$ wide strips of spruce with $8 \mathrm{~m}$ wide gaps for machine access and bunched logs. A $60 \mathrm{~m}$ wide road for truck/decking access into the site would also be required.

2. The relatively pure old aspen stands that are losing vigour and suffering mortality are common in some areas. (a) These stands could be clearcut with the intention that they will sucker vigorously and produce a dense stand of aspen. Frequently, however, the suckering is erratic in distribution and not vigorous. The reasons for this are not clear; it may relate to root dieback and low carbohydrate levels in the parent aspen trees or the cool soils and competition from well-established beds of Calamagrostis and shrub in the understory of the original stand. (b) These stands could be moved to a coniferous dominated system by underplanting 10 or more years prior to harvesting the aspen. Since the overstory is relatively open there is a well-developed understory layer. Heavy mechanical site preparation and brush control applied to relatively wide strips of understory would be required to control this vigorous vegetation. The understory protection techniques would be applied during harvest of the aspen but it is likely that value of the wood would not offset the cost of the planting and logging operations. (c) These stands might also be converted to relatively pure spruce stands by clearcutting, heavy site preparation, planting with large white spruce stock followed by vegetation control in the next decade.
3 (a) Conifer dominated stands can be clearcut and allowed to sucker back to relatively pure stands of aspen. Only about 125 stems ha ${ }^{-1}$ or $5 \mathrm{~m}^{2} \mathrm{ha}^{-1}$ are required in the residual stand to produce a fully stocked aspen stand in the second rotation (Doucet 1989). (b) If these clearcut sites are given immediate light site preparation and planted or seeded to white spruce, a twostory stand structure will develop, with aspen in the overstory and the more slow growing white spruce forming an understory. (c) If there are vegetation management treatments a decade after establishment, part or all of the aspen overstory could be removed to release the white spruce and place it in the dominant position. (d) Shelterwood systems using large windfirm spruce as shelter/seed trees and blading or mixing site preparation could result in good natural regeneration provided there were seed crops at the appropriate time and adequate seed beds in the understory. Failing adequate natural regeneration, or if more certainty of white spruce regeneration were required, planting could be done either immediately following site preparation or when an early regeneration assessment showed inadequate establishment. Some of the issues that remain unresolved relate to the residual stocking of the seeding cut, the site conditions and mechanisms to promote both white spruce and aspen, and which site conditions tend to lead to the development of balsam fir which is generally considered to be an undesirable species in the prairie provinces. (e) Leave for natural techniques could be applied. Here windfirm seed tree clusters could be left standing in strategic locations and the remaining area allowed to sucker to aspen. The predicted stocking of white spruce regeneration would be based upon the structure and composition of the stand, and the records of spruce regeneration from similar stands, including anticipated regeneration lag. These latter two systems may be inexpensive but the regeneration lag might result in loss of allowable cut of the spruce component unless the mixedwood land area was increased at the expense of pure aspen stands. (f) Group selection cuttings could be applied to remove patches of forest in openings one-two tree heights in diameter (Smith 1986). Here the mosaic of different ages of patches would regenerate to a mixture of deciduous and coniferous species. These types of stands would have a high edge to interior ratio which may be a disadvantage to some wildlife species (Hunter 1991).

\section{Multi-storied Stands}

4. Aspen dominated stands with a low understory of white spruce would be harvested with understory protection similar to $1 \mathrm{~b}$.

5. Aspen dominated stands with a tall understory could be cut gradually with wind protection techniques similar to $1 \mathrm{c}$.

6. (a) Aspen dominated overstories with understory spruce of a wide size and age range could also be cut gradually using wind protection systems to release the understory spruce. Since these spruce are unevenaged, these stands could be moved into a spruce-dominated single tree selection system with relatively little difficulty compared to the difficulty of converting an evenaged stand into an unevenaged system. (b) A second option for these stands is to cut the taller understory at the time of removing the aspen. Provided that there was sufficient smaller white spruce, this might provide an immediate yield of conifer pulp and allow the release of the shorter white spruce trees. 
7. (a) Conifer dominated stands with a size range of understory saplings might have the larger trees removed gradually over several partial cuts, thereby slowly releasing the smaller trees. The younger spruce in these stands would be all-aged. If overstory aspen were removed early there would likely be less suckering than if aspen were left to the later cuts. (b) If the taller understory spruce were cut, the smaller understory spruce could be released in one cut and hardwoods would dominate in the areas used for logging access. (c) These stands could also be moved into the single-tree selection system. This is a more complicated management system with high logging costs (Smith 1986) and it would likely be best suited to areas with high wildlife and recreation values. Two questions related to this system are: can the shade-tolerant aspen be maintained with single tree selection systems; and what are the appropriate target basal areas and species compositions which must be met to perpetuate this system?

8. Stands with scattered patches of advance regeneration separated in an irregular mosaic of spruce-dominated mixedwoods could be managed by irregular shelterwood systems. Using shelterwood cutting techniques these patches of advance regeneration could be enlarged to eventually regenerate the entire stand. The regenerated stand, however, would have a wider range of ages than a uniform shelterwood.

\section{Discussion}

Ecologically-based mixedwood management should sustain more ecosystem components than the current management system (Hunter 1991). It may also yield economic benefits in that there may be greater total yield from forests that are managed as mixtures than as single species systems. Also, natural regeneration and other systems that take advantage of natural processes within these ecosystems may cost less than systems requiring a large amount of intervention in the ecosystem. Lastly, implementation of this type of management, with a much wider range of stand structures, is likely to result in more security of tenure for industrial forestry on public lands.

To allow both intensive and semi-natural management of mixedwoods within a management unit (Lieffers and Beck 1994) there will need to be flexibility in policy and practices of both corporate and regulatory groups: (1) Currently mixedwood forests are mostly designated as either coniferous or deciduous landbase, and the rights to cut a particular species have been allocated to a particular company. The problem of overlapping coniferous and deciduous cutting rights, and often conflicting management goals, on the same land area might be addressed by having a unified management approach for the mixedwood land area. The companies involved should co-operate with each other to develop stand structure targets for all of the lands in a management unit. In this way the goals for stand structure for both ecological reasons and the timber supply for each species can be met. (2) The current regeneration regulations were developed with a coniferous bias, at a time when clearcutting was virtually the only method of harvest. The regeneration standards for the mixedwood landbase must be revised to accommodate the various systems that are used to initiate the range of desired stand structures. Regeneration standards must allow a much wider range of initial stand compositions and growth rates than are currently allowed. (3) Growth and yield estimation and determination of allowable cut must be directly linked to the composition and growth of regenerated stands. After cutting, forests must be regenerated, but the composition and timing of establishment of regeneration could vary widely depending upon objectives. Any changes in stocking of a particular species should have an immediate effect on the allowable cut of that species. The recent developments in GIS and growth modelling should provide the capabilities to use a wide variety of stand structures and compositions as inputs to the growth modelling process. Given the current limitations in data, modelling with assumptions of growth under various conditions could be used as a stopgap measure until empirical data on the growth of various stand compositions can be gathered. (4) Some management systems that are done primarily for ecosystem benefits may be difficult or expensive to implement. Given that these systems are developed primarily for the public good, it is possible that incentives such as reduced timber dues may be appropriate to encourage their development.

The set of silvicultural options proposed in this paper is a preliminary and by no means exhaustive discussion of the possible management strategies of the white spruce-aspen boreal mixedwood forest. While we acknowledge the need for further innovations, we feel that the proposed treatments will allow managers to begin to develop stands that more closely approximate the range of structures that result as mixedwood stands go through natural stand development.

\section{Acknowledgments}

We thank Permanand Sieusahai, Wayne Johnson and Stan Navratil for discussions on this topic and K. Stadt and S. Landhäusser for graphics.

\section{References}

Achuff, P.L. and G.H. La Roi. 1977. Picea-Abies forests in the highlands of northern Alberta. Vegetatio 33: 127-146.

Anonymous. 1985. Alberta phase 3 forest inventory: yield tables for unmanaged stands. Alberta Energy and Natural Resources, ENR Rep. 60a.

Benson, C.A. 1988. A need for extensive forest management. For. Chron. 64: $421-430$.

Bergeron, Y. and M. Dubuc. 1989. Succession in the southern part of the boreal forest. Vegetatio 79: 51-63.

Brace, L. and I.E. Bella. 1988. Understanding the understory dilemma and opportunity.pp. 69-86. In Management and utilization of northern mixedwoods. J.K. Samoil (Ed.). Can. For. Sev. Info. Rep. NOR-X-296.

Burkhart, H.E. and A. Tham. 1992. Prediction from growth and yield models of the performance of mixed species stands. pp. 21-34. In The ecology of mixed species stands. M.G.R. Cannell, D.C. Malcolm, and P.A. Robertson (Eds.). Blackwell Scientific, London.

Burton, P.J., A.C. Balisky, L.P. Coward, S.G. Cumming and D.D. Kneeshaw. 1992. The value of managing for biodiversity. For. Chron. 68: 225-237.

Carleton, T.J. and P.F. Maycock. 1978. Dynamics of the boreal forest south of James Bay. Can. J. Bot. 56: 1157-1173.

Cogbill, C.V. 1985. Dynamics of the boreal forests of the Laurentian highlands. Can. J. For. Res. 15: 252-261.

Corns, I.G.W. and R.M. Annas. 1986. Field guide to forest ecosystems of west-central Alberta. Northern Forestry Centre. Forestry Canada, Edmonton, AB.

DeLong, C. 1991. Dynamics of boreal mixedwood ecosystems. pp. 30-31. In Northern mixedwood '89. A. Shortreid (Ed.). Proc. Symp., Sept. 12-14, 1989. Fort St. John, B.C. Pacific Forestry Centre. Victoria, B.C. FRDA Rep. 164.

Dix, R.L. and J.A. Swan. 1971. The role of disturbance and succession in upland forest at Canadle Lake, Saskatchewan. Can. J. Bot. 49: 657-676. 
Drew, T.J. 1988. Managing white spruce in Alberta's mixedwood forest: the dilemma. pp. 35-40. In Management and utilization of northern mixedwoods. J.K. Samoil (Ed.). Can. For. Serv. Info. Rep. NOR-X-296.

Doucet, R. 1989. Regeneration silviculture of aspen. For. Chron. 66: 85-90.

Heinselman, M.L. 1981. Fire and succession in the conifer forests of North America. pp. 374 405. In Forest succession: Concepts and applications. D.C. West, H.H. Shugart and D.B. Botkin (Eds.). Springer-Verlag, New York.

Hunter, M.L. 1991. Wildlife, forests, and forestry: principles of managing forests for biological diversity. Prentice-Hall, Englewood Cliffs, NJ.

Kelty, M.J. 1989. Productivity of New England hemlock/hardwood stands as affected by species composition and canopy structure. For. Ecol. Manage. 28: 237-257.

Lavender, D.P., R. Parish, C.M. Johnson, G. Montgomery, A. Vyse, R.A. Willis and D. Winston. 1990. Regenerating British Columbia's forests. UBC Press, Vancouver, BC.

Lieffers, V.J. and J.A. Beck, Jr. 1994. A semi-natural approach to mixedwood management in the prairie provinces. For. Chron. 70: 260-264.

Lieffers, V.J. and K. Stadt. 1994. Growth of understory Picea glauca, Calamagrostis canadensis and Epilobium angustifolium in relation to overstory light. Can. J. For. Res. 24: 1193-1198.

Lieffers, V.J., K.J. Stadt and S. Navratil. 1996. Age structure and growth of understory white spruce under aspen. Can. J. For. Res. 26: (in press).

Lieffers, V.J., S.E. Macdonald and E.H. Hogg. 1993. Ecology of and control strategies for Calamagrostis canadensis in boreal forest sites. Can. J. For. Res. 23: 2070-2077.

McCune, B. and T.F.H. Allen. 1985. Will similar forests develop on similar sites? Can. J. Bot. 63: 367-376.

Navratil, S., K. Branter and J. Zasada. 1991. Regeneration in the mixedwoods. pp. 32-48. In Northern mixedwood'89. A. Shortreid, (Ed.). Proc. Symp., Sept. 12-14, 1989. Fort St. John, B.C. Pacific Forestry Centre. Victoria, B.C. FRDA Rep. 164.
Navratil, S., L.G. Brace, E.A. Sauder and S. Lux. 1994. Silvicultural and harvesting options to favor immature white spruce and aspen regeneration in boreal mixedwoods. Canadian For. Serv., Info Rep. NOR-X-337.

Nienstadt, H. and J.C. Zasada. 1990. Picea glauca. pp. 204-226. In Silvics of North America. Vol. 1 Conifers. R.M. Burns and B.H. Honkala (Eds.). USDA Forest Service Agriculture Handbook 654.

Oliver, C.D. 1992. Achieving and maintaining biodiversity and economic productivity. J. For. 90 (9): 20-25.

Oliver, C.D. and B.C. Larson. 1990. Forest stand dynamics. McGraw-Hill, New York, NY.

Pastor, J., R.H. Gardner, V.H. Dale and W.M. Post. 1987. Successional changes in nitrogen availability as a factor contributing to spruce decline in boreal North America. Can. J. For. Res. 17: 1394-1400.

Peterson, E.B. and N.M. Peterson. 1992. Ecology, management, and use of aspen and balsam poplar in the prairie provinces. For. Canada. Northwest Reg., North. For. Cent., Edmonton, Alberta. Spec. Rep. \#1. Rowe, J.S. 1961. Critique of some vegetational concepts as applied to the forests of northwestern Alberta. Can. J. Bot. 39: 1007-1015. Rowe, J.S. 1972. Forest regions of Canada. Dept. of Environment. Canadian Forestry Service Publ. 1300.

Rowe, J.S. 1992. The ecosystem approach to forestland management. For. Chron. 68: 222-224.

Rowe, J.S. and G.W. Scotter. 1973. Fire in the boreal forest. Quat. Res. 3: 444464.

Schier, G.A. and R.S. Johnston. 1971. Clonal variation in total nonstructural carbohydrates of trembling aspen roots in three Utah areas. Can. J. For. Res. 1:252-255.

Schier, G.A. and J.C. Zasada. 1973. Role of carbohydrate reserves in the development of root suckers in Populus tremuloides. Can. J. For. Res. 3: 243-250.

Smith, D.M. 1986. The practice of silviculture. Wiley, New York, NY. 